Муленко В. М., аспірант

Павлюк В. І., к.е.н., доцент

Національний транспортний університет

м. Київ, Україна

DOI: https://doi.org/10.30525/978-9934-26-064-3-6

\title{
ТРАНСФОРМАЦІЯ СИСТЕМИ ГЛОБАЛЬНОГО ПОДІЛУ ПРАЦІ В УМОВАХ ПАНДЕМІЇ
}

Поширення коронавірусу спровокувало глибоку глобальну економічну кризу. Пандемії нанесла серйозний удар по всіх галузях світової економіки, а впроваджені на ії фоні карантинні заходи призвели до сповільнення процесів глобалізації. Значно постраждав від коронавірусу глобальний поділ праці. Обмеження переміщення населення, скорочення міжнародної торгівлі, руйнування ланцюгів постачання, переорієнтація потоків капіталів на внутрішні ринки - це все негативно вплинуло на процеси міжнародної спеціалізації та кооперації. Вже зараз можна стверджувати, що наслідки пандемії матимуть довгостроковий характер та змінять економічне життя у всьому світі.

Говорячи про вплив коронавірусу на глобальний поділ праці, вже зараз можна виділити декілька характерних змін, яких зазнала система поділу праці під впливом пандемії. По-перше, на сьогодні можна спостерігати початок процесів відродження виробництва у розвинутих країнах. Процеси глобалізації зумовили переміщення виробничих потужностей 3 високорозвинутих країн до країн, що розвиваються, де наявні дешевші ресурси та робоча сила. Однак, пандемія перервала ланцюги постачання та призвела до масового скорочення виробництва, що змусило керівництво розвинутих країн та транснаціональних корпорацій переглянути даний підхід. На сьогодні вже відбувається переміщення виробництва 3 країн з низькою зарплатою до країн 3 високою зарплатою, а частка промисловості у доданій вартості багатих країн зростає [1]. Це свідчить про деяку зміну парадигми прийняття підприємницьких рішень: гарантування високої 
стійкості до криз стає більш важливим для підприємців при прийнятті управлінських рішень ніж мінімізація витрат та забезпечення ефективності.

По-друге, повернення значущих виробництв до країни походження вимагатиме істотної державної підтримки. Створення нових виробничих потужностей всередині країни для зменшення залежності від імпорту, потребуватиме захисту вітчизняних постачальників, що призведе до вживання державами різних протекціоністських заходів: субсидування, підвищення імпортних мит або створення державних компаній [2]. Ці заходи призведуть до скорочення міжнародного товарообігу та підвищення цін у відповідній країні. Однак, можна очікувати значно м'якших обмежень імпорту послуг зі сторони урядів держав. Враховуючи важливість послуг в цілому, країни будуть забезпечувати, щоб введені необхідні обмеження не стали заборонними, адже вільний доступ до послуг матиме вирішальне значення для відновлення економіки після пандемії [3].

По-третє, повернення виробництв зумовить скорочення обсягів міжнародних інвестицій та міжнародного руху капіталів. Відновлення підприємств всередині країни потребуватиме істотних фінансових вливань. Тому держави та транснаціональні корпорації почнуть переорієнтовувати потоки капіталів на внутрішній ринок. Внаслідок цього країни, що розвиваються, втратять інвестиції на мільярди доларів, що негативно вплине на ix економічний розвиток та відновлення після закінчення пандемії. Крім того, підприємства почнуть створювати запаси для зменшення впливу потенційних криз в майбутньому, що стане негативним фактором витрат у довгостроковій перспективі [4]. В зв’язку з цим частина активів та капіталів підприємств буде «заморожена» в запасах, що зменшить інвестиційну спроможність підприємств. Без надходження капіталу з-за кордону країни, що розвиваються не зможуть створити інфраструктуру, необхідну для створення робочих місць всередині країни, що породить загрозу збідніння населення. 
По-четверте, пандемія провокує автоматизацію виробництва та торгівлі товарами і послугами. Підприємства та держави стимулюють розвиток та впровадження новітніх технологій, які дозволять зменшити ризики передачі вірусу. Тому компанії дедалі більше використовують машини, роботів та цифрові технології в виробничих процесах. Крім того, новітні технології розвиваються і впроваджуються в сфері послуг для зниження людського контакту (впровадження технологій дистанційного та безпілотного керування на транспорті, технологій віртуальної реальності в туризмі, 3D принтерів та модульних технологій в будівництві, телекомунікаційних технологій в науці та освіті, новітніх електронних технологій для надання фінансових послуг тощо).

По-п'яте, очікується деяке зменшення міжнародного переміщення робочої сили та трудової міграції. Пандемія стимулює розвиток новітніх технологій та автоматизації процесів виробництва, що зменшує залежність від людської праці та втрати компанії від хвороби робітників. Це та повернення виробництв до розвинутих країн призведе до втрати країнами 3 низькою вартістю робочої сили конкурентних переваг та зниження попиту на дешеву робочу силу. Крім того, пріоритет забезпечення стійкості підприємств до криз підвищить попит на більш кваліфіковану робочу силу розвинутих країн та зменшить попит на більш дешеву працю мігрантів.

По-шосте, ймовірним є поглиблення розриву в рівнях розвитку між розвинутими країнами та країнами, що розвиваються. Націоналізація або регіоналізація ланцюгів поставок внаслідок пандемії створює ризик скорочення диверсифікації постачальників у світовій економіці та зменшує можливості для економік, що розвиваються [5]. Оскільки криза сприяє використанню капіталу та технологій замість людської праці, це матиме негативні довгострокові наслідки для країн, що розвиваються, які не мають доступу до економічно цінної сировини: країни 3 дешевою робочою силою втрачають основну конкурентну 
перевагу, що призведе до зменшення потоку капіталів та ускладнення економічного розвитку цих країн.

Вплив пандемії на глобальний поділ праці не обмежується зазначеними шістьма змінами, проте ці зміни найбільше впливають на процеси міжнародної спеціалізації та відбуваються вже сьогодні. Варто зазначити, що рівень і масштаби впливу даних тенденцій на систему поділу праці будуть залежати від тривалості пандемії та ефективності дій світового співтовариства по боротьбі 3 вірусом. Вже зараз можна припустити, що найбільшим викликом для системи глобального поділу праці може стати впровадження обмежень на переміщення факторів виробництва та протекціоністської політики багатьма країнами світу. Разом з тим, більшість економістів вважають, що пандемія не призведе до початку процесів деглобалізації та краху системи поділу праці [6]. Безсумнівним, однак, залишається факт, що система глобального поділу праці істотно зміниться в посткоронавірусний період щоб більш адекватно відповідати новим реаліям існування, забезпечити учасникам системи ефективне економічне відновлення та гарантувати більшу стійкість економік країн до майбутніх криз.

\section{Література:}

1. Kemal Kilic, Dalia Marin. How COVID-19 is transforming the world economy. VoxEU. The Centre for Economic Policy Research. URL: https://voxeu.org/article/how-covid-19-transforming-world-economy (дата звернення: 12.03.2021).

2. Thieß Petersen. Five potential effects of the corona pandemic on the international division of labor. Bertelsmann Stiftung. URL: https://ged-project.de/trade-andinvestment/five-potential-effects-of-the-corona-pandemic-on-the-internationaldivision-of-labor/ (дата звернення: 12.03.2021).

3. Anirudh Shingal. Services trade and COVID-19. VoxEU. The Centre for Economic Policy Research. URL: https://voxeu.org/article/services-trade-and-covid-19 (дата звернення: 12.03.2021).

4. Nicolas Martin. Coronavirus puts global division of labor to the test. Deutsche Welle (DW). URL: https://www.dw.com/en/coronavirus-puts-global-division-oflabor-to-the-test/a-53654974 (дата звернення: 12.03.2021).

5. Adnan Seric, Holger Görg, Saskia Mösle and Michael Windisch. How the pandemic disrupts global value chains. Industrial analytics platform. UNIDO. 
URL: https://iap.unido.org/articles/how-pandemic-disrupts-global-value-chains (дата звернення: 12.03.2021).

6. Mihir Bholey. View: Coronavirus pandemic may force world to rethink globalization. The Economic Times. URL: https://economictimes.indiatimes.com/ news/international/business/view-coronavirus-pandemic-may-force-world-to-rethinkglobalization/articleshow/75772248.cms?from=mdr (дата звернення: 12.03.2021). 